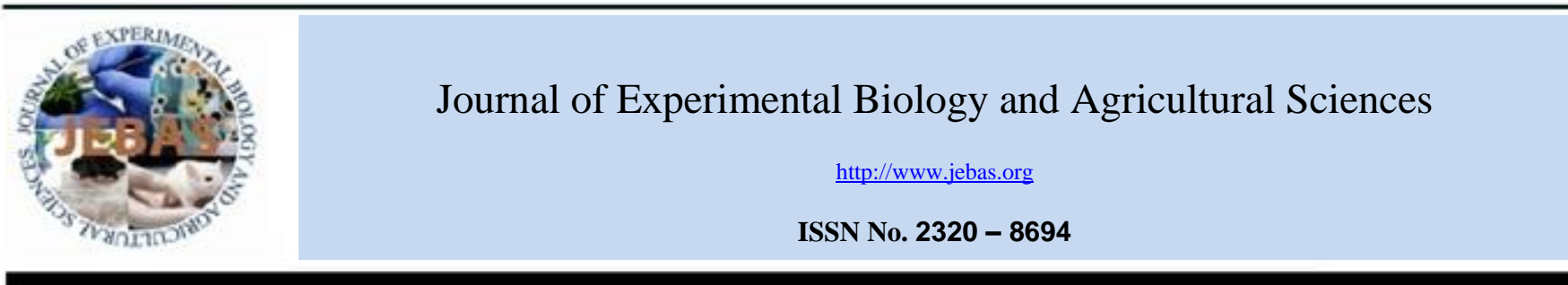

\title{
ANALYSING THE PHYLOGENETIC STATUS OF SEVEN SPECIES OF THE SUPERFAMILY COREOIDEA (INSECTA: HEMIPETRA: HETEROPTERA) FROM SOUTH INDIA
}

\author{
Bindu PU, Sebastian CD* \\ Molecular Biology Laboratory, Department of Zoology, University of Calicut, Calicut University P.O., Kerala, India -673635 \\ Received - September 25, 2019, 2019; Revision - November 01, 2019, 2019; Accepted - November 28, 2019 \\ Available Online - December 25, 2019
}

DOI: http://dx.doi.org/10.18006/2019.7(6).593.599

\section{KEYWORDS \\ $\mathrm{mtCO} 1$ \\ Heteroptera \\ Coreoidea \\ Kerala}

\begin{abstract}
Coreoidea is one of the Superfamily in Heteropteran suborder of class Insecta. Most of the Coreoid bugs are pests since they cause damage to many economically important crops. In the present work, eight specimens of seven species belonging to the three families of Superfamily Coreoidea from Kerala have been presented. The Mitochondrial Cytochrome Oxidase 1 sequences of these specimens are compared with the world database. One of among them is a new submission from the world, while others are pioneer submissions from Kerala, India. This study proves that CO1 barcoding is an excellent molecular tool for species level identification of unknown taxa.
\end{abstract}

* Corresponding author

E-mail: drcdsebastian@gmail.com (Sebastian CD)

Peer review under responsibility of Journal of Experimental Biology and Agricultural Sciences.

Production and Hosting by Horizon Publisher India [HPI] (http://www.horizonpublisherindia.in/).

All rights reserved.
All the articles published by Journal of Experimental Biology and Agricultural Sciences are licensed under a Creative Commons Attribution-NonCommercial 4.0 International License Based on a work at www.jebas.org.

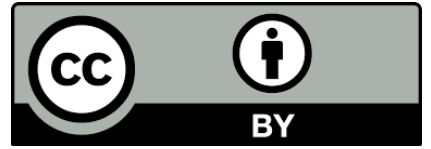




\section{Introduction}

Heteroptera the suborder under order Hemiptera consists of "true bugs". The presence of hemelytra - the front wings with hardened basal portion and membranous apical portion- is the characteristic feature of Heteropteran bugs (Charles \& Norman, 2005). The infraorder Pentatomomorpha is a large group comprising numerous bugs which are completely terrestrial with the presence of conspicuous antennae. Most of the members are phytophagus mainly feeding on saps of fruits and flowers, or seed-eaters (Tembe et al., 2014). Pentatomomorpha consists of 5 superfamilies viz., Aradoidea, Pentatomoidea, Coreoidea, Lygaeoidea, Pyrrhocoroidea (Abdul et al., 2016). Three families namely, Alydidae (Broad headed bugs), Coreidae (Leaf footed bugs), and Rhopalidae (Scentless plant bugs) are under the Superfamily Coreoidea. Most of the members of these groups are pests of many crops causing economic damages. Coreid bugs are moderately sized with scent glandsthat open on the sides of the thorax. The alydid bugs are having broad head with long and narrow body (Charles \& Norman, 2005). The Rhopalid bugs differ from the above two groups in lacking scent glands. Usually the Rhopalids are misidentified with other group of bugs due to the small size and body colourations (Kaur \& Sekhon, 2017).

DNA barcoding is a taxonomic method that uses short molecular markers in an insect's DNA for its identification. By using this method, identification of the insect species can be done at any of its developmental stage. Mitochondrial cytochrome oxidase gene is largely used for identifying due to its cost effectiveness, reliability etc (Kaur \& Sekhon, 2017). CO1 sequences helps to identify and differentiate between insects, birds and fishes. The results of Hebert's studies proved that CO1 based identification system is highly effective for animal life except the cnidarians. The genome of cnidarians is very slow in the case of evolution when compared to other animals. Hence, they have no sufficient gap between the inter and intra specific genetic variation values and thus it's difficult to differentiate between two species (Hebert et al., 2003). However, the status of molecular barcoding as a tool in identifying is far behind when compared to the classical morphological taxonomy. The number of barcodes generated from India is only $4.6 \%$ among the 59,000 morphologically identified species (Jalali et al., 2015). Thus Molecular barcoding is an emerging area for identification in the world scenario.

Although CO1 sequences were used to identify different organisms, it was by Damgaard (2008) and Memon et al. (2006), those who initial works on identifying heteropterans using the CO1 sequences. Recently Jung et al. (2011) and Park et al. (2011) proved the successfulness of CO1 sequences in identifying the heteropterans. In India, recently barcoding works on Pentatomorpha bugs of Western Ghats of India was done using cytohrome oxidase 1 gene sequences (Tembe et al., 2014).
In 2017, six species of Rhopalidae family from India were analyzed by the same method (Kaur \& Sekhon, 2017). The present study deals with the use of $\mathrm{CO} 1$ barcods in identifying seven species of Superfamily Coreoidea belonging to three families, using the Neighbor-Joining approach with the bootstrapping method and the Kimura-2 parameter to get phylogenetic results.

\section{Materials and Methods}

The eight adult heteropterans belonging to three families of Superfamily Coreoidea were collected from different parts of Kerala (Figure $1 \&$ Table 1). Preliminary identification was done using taxonomic guideline (Schuh \& Slater, 1995). Then the specimens were rechecked and confirmed by comparing with already identified deposits of specimen by the entomologists, Professor Hemant V. Ghate of Department of Entomology, Modern College, Pune and Dr. S. Salini, Scientist, Division of Insect Systematics, National Bureau of Agricultural Insect Resources, Bengaluru. The identified specimens were photographed and stored at $-20^{\circ} \mathrm{c}$ in Molecular Biology Laboratory, Department of Zoology, University of Calicut, Kerala as vouchers.

DNA from the bugs was extracted from leg tissues using commercially available DNA extraction kit by following the manufacturer instructions. The isolated DNA was confirmed using 1\% Agarose gel. Then isolated DNA was PCR amplified using appropriate forward and reverse primers (Table 2). The thermo cycler conditions were slightly modified from previous studies and is as follows; 1 initial cycle of 5 minute at $95^{\circ} \mathrm{C}$ followed by 30 cycles of $95^{\circ} \mathrm{C}$ for 10 seconds, $50^{\circ} \mathrm{C}$ for 1 minute, $72^{\circ} \mathrm{C}$ for 45 seconds followed by a final step of $72^{\circ} \mathrm{C}$ for 3 minutes (Jung et al., 2011; Park et al., 2011; Tembe et al., 2014). The PCR product was confirmed using $2 \%$ Agarose gel electrophoresis and were sequenced with both forward and reverse primers using automated sequencer ABI 3730XL by Sanger's dideoxy sequencing method.

Eight Cytochrome oxidase 1 gene sequences of the range 455 617 base pairs were obtained. The sequences were analysed for the gaps and nonsense codons, and aligned manually by using Bioedit software (Hall,1999). The final sequences of eight bugs of Coreoidea Superfamily were submitted to NCBI-GenBank and accession numbers were procured (Table 1). The sequences that are conspecific and congeneric were taken from GenBank for further phylogenetic analysis. Phylogenetic analyses and the intra and interspecific divergence among the bugs were calculated by Kimura 2 Parameter (Kimura, 1980) with the help of MEGA 6 (Tamura et al., 2013) software. The evolutionary relationships of bugs were studied and phylogenetic tree was inferred with the help of K2P model of substitution by using MEGA 6 . 

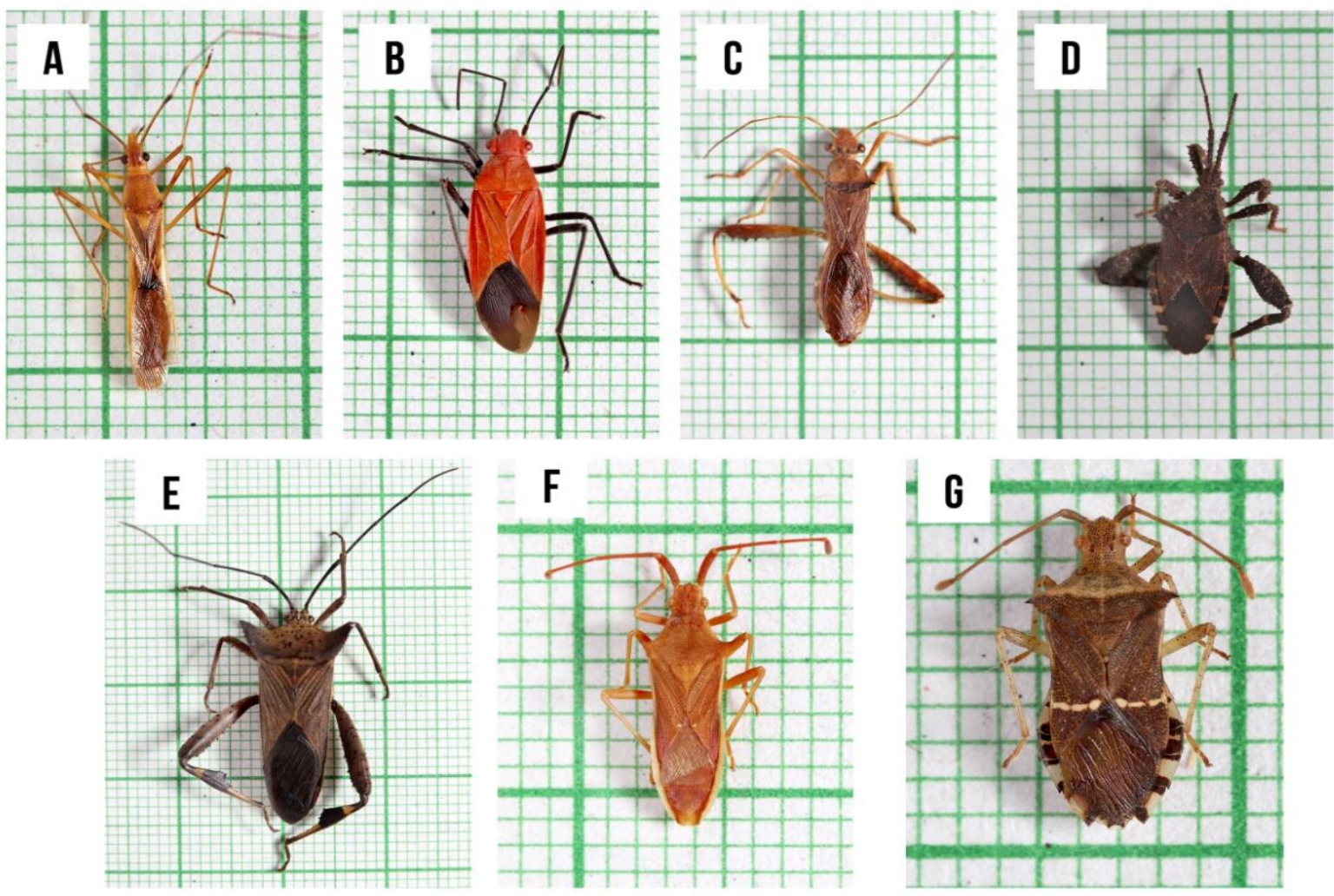

Figure 1 Photographs of A) Leptocorisa varicornis B) Leptocoris augur C) Riptortus pedestris D) Acanthocoris scabrator E) Trematocoris lobipes F) Cletus puntiger G) Cletomorpha hastate

Table 1 The collected specimen details including place and date of collection, base pair length and GenBank accession numbers respectively

\begin{tabular}{|c|c|c|c|c|c|c|}
\hline $\begin{array}{l}\text { Sl. } \\
\text { No. }\end{array}$ & Taxa name & Family & Place of Collection & $\begin{array}{l}\text { Date of } \\
\text { Collection }\end{array}$ & $\begin{array}{l}\text { Length of } \\
\text { segment (bp) }\end{array}$ & $\begin{array}{c}\text { GenBank } \\
\text { Accession No: }\end{array}$ \\
\hline 1. & $\begin{array}{l}\text { Leptocorisa varicornis } \\
\quad \text { (Fabricius 1803) }\end{array}$ & Alydidae & $\begin{array}{l}\text { Chemmappilly, } \\
\text { Thrissur, Kerala }\end{array}$ & 26.04 .2016 & 455 & KX603664 \\
\hline 2. & $\begin{array}{l}\text { Leptocoris augur } \\
\text { (Fabricius, } 1781 \text { ) }\end{array}$ & Rhopalidae & $\begin{array}{l}\text { Peringottukara, } \\
\text { Thrissur, Kerala }\end{array}$ & 25.04 .2016 & 581 & KX503052 \\
\hline 3. & $\begin{array}{l}\text { Leptocoris augur } \\
\text { (Fabricius,1781) }\end{array}$ & Rhopalidae & $\begin{array}{c}\text { Kakkodi, Kozhikode, } \\
\text { Kerala }\end{array}$ & 16.02 .2017 & 601 & MK363262 \\
\hline 4. & $\begin{array}{l}\text { Riptortus pedestris } \\
\text { (Fabricius,1775) }\end{array}$ & Alydidae & $\begin{array}{l}\text { Peringottukara, } \\
\text { Thrissur, Kerala }\end{array}$ & 25.04 .2016 & 580 & KX503048 \\
\hline 5. & $\begin{array}{c}\text { Acanthocoris scabrator } \\
\text { (Fabricius, 1803) }\end{array}$ & Coreidae & $\begin{array}{l}\text { Cherpulassery, } \\
\text { Palakkad, Kerala }\end{array}$ & 15.09.2017 & 617 & MK386670 \\
\hline 6. & $\begin{array}{l}\text { Trematocoris lobipes } \\
\text { (Westwood,1842) }\end{array}$ & Coreidae & $\begin{array}{l}\text { Cherpulassery, } \\
\text { Palakkad, Kerala }\end{array}$ & 15.09.2017 & 556 & MK363264 \\
\hline 7. & Cletus Punctiger (Dallas,1852) & Coreidae & $\begin{array}{l}\text { Shoranur, Palakkad, } \\
\text { Kerala }\end{array}$ & 24.04 .2017 & 601 & MK363261 \\
\hline 8. & $\begin{array}{l}\text { Cletomorpha hastata } \\
\text { (Fabricius, 1787) }\end{array}$ & Coreidae & $\begin{array}{c}\text { Kalladi, Wayanad, } \\
\text { Kerala }\end{array}$ & 16.04 .2017 & 596 & MK363263 \\
\hline
\end{tabular}

Journal of Experimental Biology and Agricultural Sciences http://www.jebas.org 
Table 2 List of Primers used for isolating Mitochondrial CO1 gene sequences

\begin{tabular}{|c|c|c|c|}
\hline $\begin{array}{l}\text { Sl. } \\
\text { No. }\end{array}$ & $\begin{array}{c}\text { Primer } \\
\text { Name }\end{array}$ & Primer Sequence & Species Name \\
\hline \multirow{2}{*}{1} & \multirow{2}{*}{ BUG } & $\begin{array}{l}\text { Forward: } \\
\text { 5'- CGAATTGAGTTAGGTCAACCCG - 3' }\end{array}$ & \multirow{2}{*}{ Leptocorisa varicornis (KX603664) } \\
\hline & & $\begin{array}{l}\text { Reverse: } \\
\text { 5'- GGATCTCCTCCTCCTGAAGGATC - 3' }\end{array}$ & \\
\hline \multirow{2}{*}{2} & \multirow{2}{*}{ FOM } & $\begin{array}{l}\text { Forward: } \\
\text { 5'- GGTCAACAAATCATAAAGATATTGG -3' }\end{array}$ & \multirow{2}{*}{$\begin{array}{l}\text { Riptortus pedestris (KX503048) } \\
\text { Leptocoris augur (KX503052) }\end{array}$} \\
\hline & & $\begin{array}{l}\text { Reverse: } \\
\text { 5'- TAAACTTCAGGGTGACCAAAAAATCA -3' }\end{array}$ & \\
\hline \multirow{2}{*}{3} & \multirow{2}{*}{ LEPTO } & $\begin{array}{l}\text { Forward: } \\
\text { 5'- CATTGGAGATGACCAAATTTATAATG -3' }\end{array}$ & \multirow{2}{*}{$\begin{array}{l}\text { Leptocoris augur }(\mathrm{MK} 363262) \\
\text { Trematocorislobipes }(\mathrm{MK} 363264) \\
\text { Acanthocoris scabrator }(\mathrm{MK} 386670 \\
\text { Cletus punctiger }(\mathrm{MK} 363261) \\
\text { Cletomorpha hastata }(\mathrm{MK} 363263)\end{array}$} \\
\hline & & $\begin{array}{l}\text { Reverse: } \\
\text { 5'- TGAAATTAATCCAAATCCAGGTAAA -3' }\end{array}$ & \\
\hline
\end{tabular}

Table.3: Comparing sequence divergence at different taxonomic levels using K2P model of present study with previous studies

\begin{tabular}{|ccccccc|}
\hline & \multicolumn{2}{c}{ Present Study } & \multicolumn{2}{c|}{ Sanketet al., 2014 } \\
Range & $\begin{array}{c}\text { Mean Distance } \\
(\%)\end{array}$ & $\begin{array}{c}\text { Range } \\
(\%)\end{array}$ & $\begin{array}{c}\text { Mean Distance } \\
(\%)\end{array}$ & $\begin{array}{c}\text { Park et al., 2011 } \\
(\%)\end{array}$ & $\begin{array}{c}\text { Mean Distance } \\
(\%)\end{array}$ \\
\hline $\begin{array}{c}\text { Intra-specific } \\
\text { divergence }\end{array}$ & $0-1.22$ & 0.53 & $0-2.1$ & 0.4 & $0-7.72$ & 0.74 \\
\hline $\begin{array}{c}\text { Inter-specific } \\
\text { divergence }\end{array}$ & $0-23.38$ & 18.48 & $0-19.8$ & 11.7 & $0-24.80$ & $0-35.80$ \\
\hline $\begin{array}{c}\text { Inter-generic } \\
\text { divergence }\end{array}$ & $16.66-22.71$ & 19.73 & $11.8-24.4$ & 14.9 & $12.15-36.67$ \\
\hline $\begin{array}{c}\text { Inter-family } \\
\text { divergence }\end{array}$ & $18.64-20.33$ & 19.32 & $18.0-30.2$ & 21.0 & & 23.66 \\
\hline
\end{tabular}

\section{Results and Discussion}

The current work is based on total 59 mitochondrial CO1 sequences in which, eight sequences are of the Coreoidea Superfamily of this study (Table 1) and remaing 51 sequences of bugs are retrieved from NCBI-GenBank with a pentatomid bug, Tetroda histeroides (Fabricius) - Acc no: MK386675, taken as the outgroup. The $8 \mathrm{CO} 1$ sequences obtained in this work are not pseudogenes since they lack stop codons or frame shifts. All obtained sequences were more than 450 bp length (Table.1). 50 sequences of species belonging to Superfamily Coreoidea were retrieved from NCBI GenBank for the analysis. The final aligned data had total 59 sequences including the outgroup with 461 bp length. Since $T$. lobipes from this study is a new addition to the GenBank barcode database, no conspecific sequence obtained during the BLAST analysis.

The divergences in different taxonomic levels were calculated using Kimura 2 Parameter of MEGA 6. The results are shown in Table 3. It is clear that there is a hierarchial increase in mean divergence across the taxonomic levels which were proved in previous studies (Jung et al., 2011; Park et al., 2011; Tembe et al., 2014). In this study, mean divergence intraspecifiaclly was $0.53 \%$ (SE.0.20\%) and the range was $0-1.22 \%$ while, interspecific divergence showed average of $18.48 \%$ (SE 2.13\%) and the range was $0-23.30 \%$. Divergence among the genera averaged $19.73 \%$ (SE 2.04\%). The range of divergence among genera in a family was $16.66 \%-22.71 \%$. In the case of families, the divergence between the three families of this study averaged $19.32 \%$ (SE $1.72 \%$ ) with a range of $18.64 \%$ $20.33 \%$.The variations seen in the values of this study when compared to the others (Table 3) can be attributed to the difference in total number of specimens taken for analysis.

Neighbor Joining was the method used to analyze the evolutionary history and an optimal tree with a total of branch length = 2.22071201 has obtained as in Figure 2 (Saitou \& Nei, 1987). The percentage replicate of trees is shown next to the branches in which the related taxa grouped together in the bootstrap test (1000 replicates) (Felsenstein, 1985). The evolutionary tree is drawn to scale, with branch lengths in the same units as those of the 


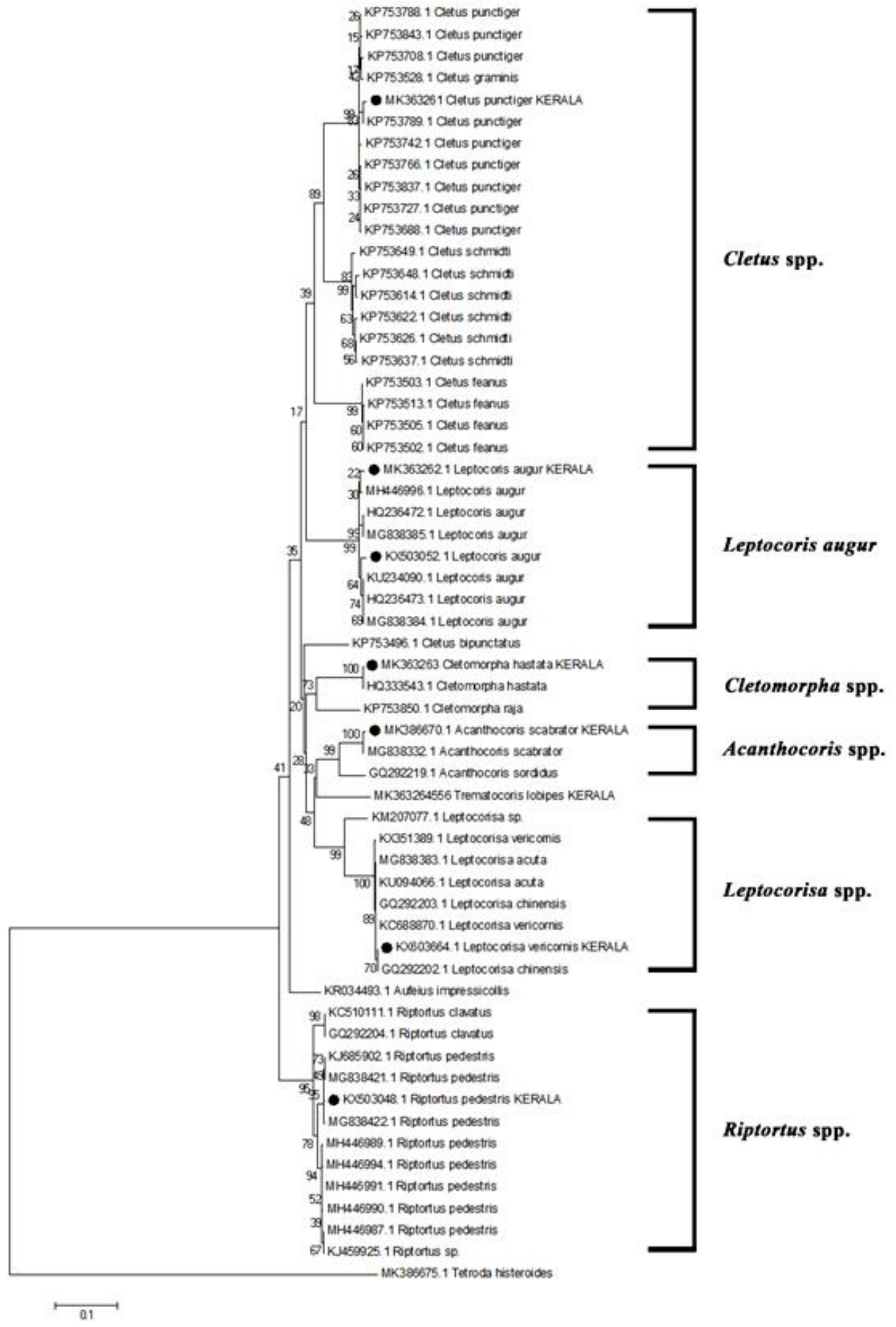

Figure 2 Phylogenetic tree og bugs of Superfamily Coreoidea based on CO1 gene sequences using K2P model and NJ method using MEGA6 software. The species of present study are labeled.

Journal of Experimental Biology and Agricultural Sciences http://www.jebas.org 
evolutionary distances used to infer the phylogenetic tree. Kimura 2-parameter is the method selected for calculating evolutionary distances (Kimura, 1980) and is in the units of the number of base substitutions per site. The analysis is done with 59 nucleotide sequences. Codon positions included $1 \mathrm{st}+2 \mathrm{nd}+3 \mathrm{rd}+$ Noncoding. All ambiguous positions were removed for each sequence pair. There were a total of 461 positions in the final dataset. Evolutionary analyses were conducted in MEGA6 (Tamura et al., 2013). In the neighbour-joining tree for all sequences, two clades were obtained: the first cluster consisting of all Riptortus species of family Alydidae and the other consisting of all other species taken in study. In this tree, closely related species are clustered together and separated from other species. The CO1 sequences of present study are grouped with other conspecific sequences retrieved from GenBank, confirming its identification. T. lobipes of the present study is standing alone since there was no other conspecific or congeneric sequence in the database. Hence this mitochondrial sequence is new contribution to the database by this study. Different species of Cletus got separated from same node except in case of $C$. bipunctatus.

The members of $C$. punctiger, C. schmidti and C. feanus are having a common ancestor. The $C$. punctiger of present study shares node with conspecific from China. Leptocoris augur, Acanthocoris scabrator, Cletomorpha hastata of this study is showing greatest similarity with its conspecific Indian sequences. All members of Leptocorisa genus are clustered together. Leptocorisa varicornis of present study is showing barcode sharing with $L$. chinensis from Korea is similar to the results of Tembe et al. (2014). All members of Riptortus genus are clustered separately in the phylogenetic tree when other members of the superfamily Coreoidea including the family Alydidae in which Riptortus genus is present, are clustered together. Since $R$. pedestris is a widespread species, it is likely to show considerable genetic variation to adapt to different environments and the distinct separate clustering then can be attributed to its high intraspecies divergence (Tembe et al., 2014).

The intraspecific divergence should be much less than the interspecific divergence is the key of species identification using molecular marker like CO1 sequences (Tembe et al., 2014). This is confirmed by this study as the intraspecific and inter specific divergence are $0.53 \%$ and $18.48 \%$ respectively. Thus the present work shows the usefulness of mitochondrial CO1 gene sequences in the identification and conservation of the evolutionary processes that generate and preserve biodiversity. DNA barcoding techniques greatly favor the taxonomic studies. Molecular studies coupled with classical taxonomic works will help in the current biodiversity crisis. The specimens of current work belong to pest category since they cause destructive effects on crops. The accurate and speedy identification of the pests are needed for a suitable pest control strategy.
Thus DNA barcoding and CO1 sequences are also helpful in simple and rapid identification of invasive species and destructive pests and also contributing to the world biodiversity database.

\section{Conclusions}

Our study results reveal that mitochondrial $\mathrm{CO} 1$ barcoding will help for the identification of insect species quickly. An accurate knowledge of this method is required for the proper use of it. Present work contributes mitochondrial CO1 sequences to the barcode data of bugs by the addition of data from Southern parts of India. Only if the database is kept robust and renewed, the identification and comparison of species all around the world will be easy. It also aids the researches to identify and study about the cryptic and polymorphic forms.

\section{Acknowledgements}

Authors would like to thank Dr. S. Salini Scientist, Division of Insect Systematics, National Bureau of Agricultural Insect Resources, Bengaluru, India and Prof. Hemant V. Ghate of Department of Entomology, Modern College, Pune for the identification of specimens. Thanks to UGC- Maulana Azad National Fellowship scheme for the funding assistance. All facilities for the work were provided by Molecular Biology Laboratory, Department of Zoology, University of Calicut, Kerala. We also appreciate help from our friends in specimen collection and for constant support

\section{Conflict of Interest}

The authors declare that they have no conflict of interest.

\section{References}

Abdul JK, Imran K, Maqsood AR, Muhammad SW, Waheed AP (2016) Records of pentatomorpha (hemiptera) in fauna of british india with in present boundaries of Pakistan. Pakisthan. Journal of Entomology 31: 183-187.

Charles AT, Norman FJ (2005) Borror and Delong's introduction to the study of Insects. Seventh edition Thomson Brooks/Cole pg 268.

Damgard J (2008) MtDna diversity and species phylogeny of western Palaearctic members of Gerrislaustris group (Hemiptera: Heteroptera: Gerrida) with implications for DNA barcoding of water striders. Insect Systematics and Evolution 39:107-120.

Felsenstein J (1985) Confidence limits on phylogenies: An approach using the bootstrap. Evolution 39:783-791.

Hall TA (1999) Bioedit: a user-friendly biological sequence alignment editor and analysis programme for Windows 95/98/NT. Nucleic Acids Symposium series 41:95-98. 
Hebert PDN, Sujeevan R, deWaard JR (2003) Barcoding animal life: cytochrome $\mathrm{c}$ oxidase subunit 1 divergences among closely related species. Proceedings of the Royal Society B (Suppl.) Doi10.1098/rsbl.2003.0025. 270: 96-99.

Jalali S, Ojha R, Venkatesan T (2015) DNA Barcoding for Identification of Agriculturally Important Insects. In Chakravarthy A (Ed.), New Horizons in Insect Science: Towards Sustainable Pest Management. Springer, New Delhi. Pp 13-23.

Jung S, Duwal RK, Lee S (2011) CO1 barcoding of true bugs (Insecta, Heteroptera). Molecular Ecology Resources 11:266-270.

Kaur H, Sekhon NK (2017) DNA barcoding of six species of family Rhopalidae (Insecta: Hemiptera: Heteroptera) from India. International Journal of Life Sciences 5:517-526.

Kimura M (1980) A simple method for estimating evolutionary rate of base substitutions through comparative studies of nucleotide sequences. Journal of Molecular Evolution 16:111-120.

Memon N, Meier R, Manan A, Su K (2006) On the use of DNA sequences for determining the species limits of a polymorphic new species in the stink bug genus Halys (Heteroptera: Pentatomidae) from Pakistan. Systematic Entomology 31: 703-710.

Park DS, Footit R, Maw E, Hebert PDN (2011) Barcoding bugs: DNA- based identification of the true bugs (Insecta: Hemiptera: Heteroptera). Plos One 6(4): e18749. https://doi.org/10.1371/journal.pone.0018749.

Saitou N, Nei M (1987) The neighbor-joining method: A new method for reconstructing phylogenetic trees. Molecular Biology and Evolution 4:406-425

Schuh, RT, Slater JA (1995) True Bugs of the world (Hemiptera: Heteroptera). Classification and Natural History. Cornell University Press. Ithaca, New York.

Tamura K, Stecher G, Peterson D, Filipski A, Kumar S (2013) MEGA6: Molecular Evolutionary Genetics Analysis version 6.0. Molecular Biology and Evolution 30: 2725-2729

Tembe S, Yogesh S, Ghate HV (2014) DNA barcoding of Pentatomorpha bugs (Hemiptera: Heteroptera) from Western Ghats of India. MetaGene 2:737-745 